\title{
Kemampuan motorik kasar siswa sekolah dasar penderita obesitas
}

\author{
Gross motor ability of obese elementary school students
}

Isti Dwi Puspita Wati ${ }^{1}$, Woro Kushartanti ${ }^{2}$, Joko Susilo ${ }^{3}$

\begin{abstract}
Background: Childhood is the period of rapid growth and development. Various aspects can affect problems in growth and development such as genetics, natural environment, and social economic status of the family, nutrition status, social and cultural environment. Inappropriate food intake can cause malnutrition in children, both undernourishment and over nourishment (obesity). Obesity is not good for the process of child growth and development because it distorts the process of metabolism and bring risks for cardiovascular diseases.

Objective: To identify gross motor ability of obese elementary school students at Yogyakarta Municipality and evaluate motor ability of elementary school students based on degree of obesity.

Method: The study was observational with cross sectional design. Subject of the study were 158 obese elementary school students at Yogyakarta Municipality. Subjects were screened and tested using fat caliper and their height and weight were measured. If they belonged to obese their gross motor ability was tested comprising throwing with target, flexibility long jump standing, squatting, push up, balance and speed running. Data were analyzed using Spearman correlation at C195\% ( $p<0.05)$.

Result: Gross motor ability of children has negative correlation with obesity $\left(r_{\text {rho }}=-0,465\right)$, so children with heavy obesity have the bad gross motor ability. However there was no relationship between ability of flexibility, standing long jump, balance, and speed running the mobility (sig >0,05).

Conclusion: Child which progressively obesity will have a lower gross motor ability.
\end{abstract}

KEY WORDS obese children, gross motor ability

\section{ABSTRAK}

Latar belakang: Masa anak adalah masa pertumbuhan dan perkembangan yang pesat. Banyak aspek yang dapat mempengaruhi kegagalan dalam masa pertumbuhan dan perkembangan antara lain genetik, lingkungan alam, status sosial ekonomi keluarga, status gizi, lingkungan sosial, dan budaya. Kesalahan dalam asupan makanan dapat menimbulkan gizi buruk pada anak, dalam hal ini gizi kurang dan gizi lebih (obesitas). Obesitas berbahaya bagi proses tumbuh kembang anak karena mengganggu proses metabolisme serta menyebabkan risiko terkena berbagai penyakit kardiovaskuler.

Tujuan: Untuk mengetahui kemampuan motorik kasar siswa sekolah dasar (SD) penderita obesitas di Kota Yogyakarta serta untuk mengukur kemampuan motorik siswa SD berdasarkan tingkat obesitas di kota Yogyakarta.

Metode: Penelitian ini merupakan penelitian observasional dengan rangcangan cross sectional. Subjek penelitian adalah siswa SD di Kota Yogyakarta yang menderita obesitas berjumlah 158 siswa. Subjek discrenning kemudian dites dengan menggunakan fat kaliper serta diukur tinggi badan dan berat badan. Siswa yang tergolong obesitas diberi tes kemampuan motorik kasar meliputi lempar dengan target, kelentukan, standing long jump, squat, push up, keseimbangan, dan lari kelincahan. Data dianalisis dengan menggunakan uji korelasi Spearman dengan derajat kemaknaan 95\% $(p<0,05)$.

Hasil: Kemampuan motorik kasar anak berhubungan terbalik dengan tingkat obesitas $\left(r_{\text {hitung }}=-0,465\right)$, sehingga anak yang mengalami obesitas berat mempunyai kemampuan motorik kasar yang jelek. Pada kelenturan, standing long jump, keseimbangan, dan lari kelincahan tidak menunjukkan adanya hubungan dengan tingkat obesitas $(p>0,05)$.

Kesimpulan: Siswa yang menderita obesitas berat mempunyai kemampuan motorik kasar yang kurang.

KATA KUNCI: obesitas anak, kemampuan motorik kasar

\section{PENDAHULUAN}

Masa anak adalah masa pertumbuhan dan perkembangan yang pesat. Masa ini merupakan masa penentuan dalam mencapai pertumbuhan dan perkembangan yang baik di kemudian hari. Banyak aspek yang dapat mempengaruhi kegagalan dalam masa pertumbuhan dan perkembangan anak antara lain adalah genetik, lingkungan alam, status sosial ekonomi keluarga, status gizi, lingkungan

\footnotetext{
1. Fakultas Keguruan dan IImu Pendidikan, Program Studi Pendidikan Jasmani Kesehatan dan Rekreasi, Universitas Tanjungpura, Jl. Ahmad Yani Pontianak 78124 Kalimantan Barat, email: isti_mns@yahoo. com

2. Fakultas IImu Olahraga Universitas Negeri Yogyakarta, Jl. Colombo, Karang Malang, Yogyakarta 55281

3. Politeknik Kesehatan Kemenkes Jurusan Gizi, JI. Tata Bumi No 3, Banyuraden, Gamping, Sleman 55293 Yogyakarta, email: jokosusilo_ gizi@yahoo.com
} 
sosial dan budaya (1). Asupan makanan yang kurang di masa emas pertumbuhan anak akan menimbulkan efek yang buruk pada kehidupan mendatang. Dengan demikian, status gizi pada anak harus selalu dipantau sehingga kemungkinan terjadinya kegagalan pada tumbuh kembang anak dapat ditanggulangi sedini mungkin. Selain pemantauan terhadap status gizi, pemantauan terhadap pertumbuhan dan perkembangan anak juga harus ikut dipantau.

Kesalahan dalam asupan makanan dapat menimbulkan gizi buruk pada anak. Gizi buruk ini sendiri ada dua macam yaitu gizi kurang dan gizi lebih. Anak yang mengalami gizi lebih, biasa disebut dengan obesitas. Angka kejadian obesitas pada masa kanak-kanak meningkat secara cepat di seluruh dunia. Hal ini terjadi karena anak-anak menghabiskan lebih banyak waktu di depan TV, komputer atau perangkat video game daripada bermain di luar ruangan. Obesitas disebabkan oleh berbagai faktor antara lain genetik, metabolisme, kebiasaan, dan lingkungan (2). Anak obesitas mempunyai risiko tinggi terkena penyakit diabetes tipe 2 , hipertensi, penyakit jantung, sulit tidur, dan memiliki masalah psikososial (3). Hasil penelitian yang dilakukan di Yogyakarta mengenai prevalensi obesitas dan hubungan konsumsi fast food dengan kejadian obesitas pada remaja SLTP kota dan desa menunjukkan adanya hubungan frekuensi konsumsi fast food dengan kecenderungan terjadinya obesitas pada remaja SLTP kota dan desa $(p<0,05)(4)$. Prevalensi obesitas pada anak sekolah dasar di Kota Yogyakarta pada tahun 1997 sebesar 9,5\% (5).

Penelitian yang dilakukan di Amerika Serikat menyatakan bahwa menonton televisi atau video lebih dari 2 jam pada anak usia pra sekolah dihubungkan dengan risiko tinggi untuk menjadi gemuk atau obesitas (6). Obesitas berbahaya bagi proses tumbuh kembang anak karena mengganggu proses metabolisme serta menyebabkan risiko terkena berbagai penyakit kardiovaskuler seperti jantung, diabetes, gangguan pembuluh darah, dan hipertensi. Anakanak yang jarang bergerak akan lebih mudah mengalami kenaikan berat badan karena mereka tidak membakar kalori melalui aktivitas fisik. Aktivitas untuk mengisi waktu luang yang tidak membuat mereka banyak bergerak, seperti menonton televisi atau bermain video game.

Hasil penelitian pada siswa sekolah dasar di Kota Yogyakarta menunjukkan bahwa adanya hubungan antara tekanan darah sistolik dan diastolik dengan obesitas. Tekanan darah sistolik berhubungan dengan akses dari berat badan. Jika tekanan darah ini terus meningkat, anak-anak dengan tekanan darah yang tinggi dan normal-tinggi tersebut akan menderita gangguan kesehatan di tahun-tahun mendatang (7). Penelitian lain yang juga dilakukan di Kota Yogyakarta menyatakan bahwa tidak ada kaitan antara kejadian mikropenis dengan obesitas, tetapi terdapat perbedaan ratarata ukuran panjang penis anak yang berstatus gizi obes dibandingkan dengan nonobes pada kelompok menjelang pubertas sebesar 0,49 cm (IK95\%: 0,01-0,98; $p=0,04)(8)$.
Anak yang mengalami obesitas dapat mengalami gangguan dalam geraknya. Gerak anak obesitas menjadi tidak fleksibel dan terhambat. Berat badan yang berlebih membuat tubuh sulit untuk bergerak aktif seperti pada anakanak dengan berat badan normal. Anak yang memliki lemak terlalu banyak, cenderung kurang mampu mengikuti olahraga ataupun permainan sehingga seringkali tidak diikutsertakan dalam bermain (1). Anak obesitas banyak yang memiliki nilai baik pada mata pelajaran di sekolah kecuali pada mata pelajaran olahraga.

Perkembangan motorik meliputi perkembangan motorik kasar (antara lain adalah lari, lempar, lompat, dan loncat) dan perkembangan motorik halus (seperti memegang pensil, menulis, menggambar, menari, dan lain-lain). Motorik merupakan suatu kebutuhan yang harus dipelajari pada usia sekolah dasar, mengingat hal tersebut akan sangat dibutuhkan untuk menunjang perkembangan postur tubuh di masa remaja dan dewasa. Keterampilan motorik berfungsi membantu anak untuk memperoleh kemandiriannya dan membantu mendapatkan penerimaan sosial. Fungsi kemampuan motorik antara lain keterampilan bantu diri, keterampilan bantu sosial, keterampilan bermain, dan keterampilan sosial (1).

Keterlambatan perkembangan motorik lebih sering disebabkan oleh kurangnya kesempatan untuk mempelajari keterampilan motorik. Pengaruh perkembangan motorik yang kurang, berbahaya bagi penyesuaian sosial dan pribadi anak. Hal ini dapat menimbulkan masalah perilaku dan emosi, selain itu keterlambatan perkembangan motorik juga berbahaya bagi anak karena tidak menyediakan landasan untuk mempelajari keterampilan motorik selanjutnya. Berdasarkan pemikiran tersebut maka peneliti tertarik untuk melakukan survey untuk melihat kemampuan motorik kasar siswa sekolah dasar (SD) penderita obesitas di Kota Yogyakarta.

\section{BAHAN DAN METODE}

Penelitian ini merupakan penelitian observasional dengan rancangan penelitian cross sectional. Penelitian ini dilaksanakan di Kota Yogyakarta pada bulan Agustus sampai dengan Oktober 2007. Populasinya adalah semua siswa sekolah dasar (SD) kelas 2 sampai kelas 5 yang menderita obesitas dan berada di wilayah Kota Yogyakarta, baik yang berasal dari SD negeri maupuan swasta yang tercatat di Dinas Pendidikan dan Kebudayaan DIY di Kota Yogyakarta. Besar sampel diperoleh berdasarkan rumus pendugaan proporsi populasi dengan tingkat kepercayaan $95 \%$, proporsi populasi $(P)$ sebesar 9,5\% $(0,095)$, dan presisi (d) sebesar $95 \%$ (9). Berdasarkan rumus tersebut sampel yang diambil dalam penelitian ini sebesar 132 anak. Teknik pengambilan sampel dengan sistem accidental sampling, yaitu siswa yang masuk sekolah pada saat penelitian dilaksanakan dan terjaring pada tahap skrining awal. Penelitian ini dilaksanakan pada sekolah dasar (SD) yang berlokasi di Kota Yogyakarta 
yang meliputi SD Negeri Glagah 1, SD Muhammadiyah Sapen, SD Muhammadiyah Kleco, SD TM Ibu Pawiyatan, dan SD Pangudiluhur. Adapun kriteria inklusinya adalah anak tercantum dalam Dinas Pendidikan dan Kebudayaan DIY, siswa memiliki tubuh yang gemuk atau obesitas, dan bersedia mengikuti penelitian. Kriteria eksklusinya adalah siswa sedang sakit atau tidak masuk sekolah dan siswa menderita kecacatan fisik.

Variabel bebas dalam penelitian ini adalah kemampuan motorik kasar anak yaitu kemampuan seorang anak untuk melaksanakan keterampilan gerak pokok berhubungan dengan semua ciri gerak dasar mencakup koordinasi tangan dan mata, pengontrolan otot-otot besar, tes keseimbangan, kelincahan, dan kelenturan. Data kemampuan motorik kasar anak diperoleh dengan melakukan tes kemampuan motorik yaitu melempar dengan target, kelenturan pada punggung dan tungkai bagian belakang, standing long jump, push up di kursi, keseimbangan statis, dan lari kelincahan. Kemampuan motorik kasar anak pada masing-masing tes diklasifikasikan menjadi 4 kategori yaitu jelek apabila skor kurang dari 25 , kurang jika skor sama dengan 25-50, cukup jika skor sama dengan 51-75, dan baik jika skor sama dengan 76-90. Sedangkan kemampuan motorik kasar anak total dikategorikan menjadi jelek apabila skor kurang dari 200, kurang jika skor sama dengan 200-400, cukup jika skor sama dengan 401-600, dan baik jika skor sama dengan 601-720.

Variabel terikatnya adalah obesitas yaitu kelainan atau penyakit yang ditandai dengan penimbunan jaringan lemak tubuh secara berlebihan. Untuk mengetahui status gizi apakah anak menderita obesitas dilakukan dengan mengukur tebal lemak kulit pada bagian trisep dan betis serta untuk back up data diambil berat badan dan tinggi badan anak serta data usia anak. Data antropometri diperoleh dengan cara melakukan pengukuran tebal lemak bawah kulit menggunakan kaliper, yang diukur pada trisep dan betis. Selain itu juga diukur berat badan anak menggunakan timbangan dengan ketelitian $0,1 \mathrm{~kg}$. Pada saat menimbang berat badan anak, pakaian seminimal mungkin. Data tinggi badan diukur menggunakan microtoice dengan ketelitian $0,1 \mathrm{~cm}$.

Pengelompokan persentase lemak tubuh berdasarkan tebal lemak pada trisep dan betis dikategorikan menjadi: pada laki-laki tergolong obes ringan jika skor sama dengan 26-32; obes sedang jika skor sama dengan 33-40; obes berat jika skor sama dengan 41-60, dan pada perempuan tergolong obes ringan jika skor sama dengan 33-40; obes sedang jika skor sama dengan 41-50; obes berat jika skor sama dengan $51-60$ (10).

Untuk mendapatkan data yang akurat, diberikan penjelasan kepada enumerator yang berkualifikasi lulusan S-1 IImu Keolahragaan (IKORA-UNY) maupun mahasiswa tingkat akhir meliputi: penentuan subjek penelitian, teknik pengukuran antropometri, dan teknik melakukan tes kemampuan motorik anak. Khusus untuk tes kemampuan motorik dilakukan penjelasan dan cara melakukan tes sebanyak 2 kali yaitu pada 1 minggu sebelum penelitian beserta materi untuk dipelajari, dan yang kedua dilakukan satu hari sebelum penelitian dilakukan. Sebelumnya peneliti akan melakukan uji coba terhadap alat tes kemampuan motorik.

Digunakan beberapa uji statistik dengan derajat kemaknaan $95 \%$ dan $p=0,05$. Analisis yang dilakukan adalah analisis univariat untuk karakteristrik subjek penelitian dan analisis bivariat menggunakan korelasi Spearman untuk menguji korelasi antara kemampuan motorik kasar dengan obesitas.

\section{HASIL DAN BAHASAN}

\section{Karakteristik subjek}

Siswa yang menjadi subjek penelitian ini berjumlah 158 siswa yang terdiri dari 102 siswa laki-laki dan 56 siswa perempuan (Tabel 1).

Dalam penelitian ini diperoleh data dari 158 siswa SD di Kota Yogyakarta yang mengalami obesitas ringan sebanyak 19 anak laki-laki dan 28 anak perempuan. Sedangkan yang mengalami obesitas sedang sebanyak 35 anak laki-laki dan 24 anak perempuan. Demikian juga siswa sekolah dasar di Kota Yogyakarta yang termasuk dalam kategori sangat obesitas (obesitas berat) sebanyak 48 anak laki-laki dan 4 anak perempuan (Tabel 2).

Dari ketujuh item yang dites mengenai kemampuan motorik kasar, menunjukkan hasil bahwa pada kemampuan melempar, squat, keseimbangan, dan kemampuan motorik, secara keseluruhan siswa yang menderita obesitas berat mempunyai kemampuan yang jelek lebih banyak daripada siswa yang mengalami obesitas sedang dan ringan. Sedangkan pada kelenturan tubuh, semua siswa yang mengalami obesitas tidak mampu melaksanakan tes dengan sempurna, hal ini disebabkan siswa yang mengalami obesitas tersebut hampir semuanya mempunyai perut yang buncit.

\section{Hubungan kemampuan motorik kasar anak dengan obesitas}

Berdasarkan Tabel 3 maka dapat diketahui bahwa kemampuan motorik kasar anak berhubungan dengan tingkat obesitas dengan nilai $r_{\text {rho }}=-0,465$ yang keeratan hubungan tergolong sedang dan berhubungan negatif. Sehingga dapat diartikan bahwa semakin obes, kemampuan motorik kasar anak semakin rendah.

Dari ketujuh instrumen yang digunakan untuk mengetahui kemampuan motorik kasar anak (melempar, kelenturan, standing long jump, squat, push up, keseimbangan, dan lari kelincahan) yang menunjukkan adanya hubungan dengan tingkat obesitas adalah kemampuan melempar, squat, dan push up dengan hubungan yang relatif rendah dan negatif. 
Tabel 1. Distribusi karakteristik subjek penelitian

\begin{tabular}{ccccccc}
\hline Kelompok & $\begin{array}{c}\text { SD N } \\
\text { Glagah } \\
(\mathbf{n = 3 1 )}\end{array}$ & $\begin{array}{c}\text { SD M. } \\
\text { Sapen } \\
(\mathbf{n = 5 0 )}\end{array}$ & $\begin{array}{c}\text { SD M. Kleco } \\
(\mathbf{n = 3 2})\end{array}$ & $\begin{array}{c}\text { SD TM } \\
\text { Pawiyatan } \\
(\mathbf{n = 9})\end{array}$ & $\begin{array}{c}\text { SD } \\
\text { Pangudiluhur } \\
(\mathbf{n = 3 6 )}\end{array}$ & $\begin{array}{c}\text { Total } \\
(\mathbf{n = 1 5 8 )}\end{array}$ \\
\hline $\begin{array}{c}\text { Jenis kelamin } \\
\text { Laki-laki }\end{array}$ & $19(61,29 \%)$ & $39(78 \%)$ & $19(59,37 \%)$ & $6(66,67 \%)$ & $18(50 \%)$ & $102(64,6 \%)$ \\
$\quad \begin{array}{c}\text { Perempuan } \\
\text { Usia (tahun) }\end{array}$ & $12(38,71 \%)$ & $11(22 \%)$ & $13(40,63 \%)$ & $3(33,33 \%)$ & $18(50 \%)$ & $56(35,4 \%)$ \\
$<8$ & $2(6,45 \%)$ & 0 & $1(3,12 \%)$ & $4(44,44 \%)$ & $4(11,11 \%)$ & $19(12 \%)$ \\
9 & $13(41,94 \%)$ & $8(16 \%)$ & $8(25 \%)$ & $2(22,22 \%)$ & $8(22,22 \%)$ & $64(40,5 \%)$ \\
10 & $10(32,26 \%)$ & $33(66 \%)$ & $14(43,75 \%)$ & $2(22,22 \%)$ & $17(47,22 \%)$ & $52(32,9 \%)$ \\
$>11$ & $6(19,35 \%)$ & $9(18 \%)$ & $9(28,12 \%)$ & $1(11,11 \%)$ & $7(19,44 \%)$ & $23(14,6 \%)$ \\
Kelas & & & & & & \\
2 & 0 & 0 & 0 & $4(44,44 \%)$ & 0 & $4(2,5 \%)$ \\
3 & $9(29,03 \%)$ & $24(48 \%)$ & $5(15,62 \%)$ & $1(11,11 \%)$ & $9(25 \%)$ & $48(30,4 \%)$ \\
4 & $7(22,58 \%)$ & $26(52 \%)$ & $16(50 \%)$ & $3(33,33 \%)$ & $19(52,78 \%)$ & $71(44,9 \%)$ \\
5 & $15(48,39 \%)$ & 0 & $11(34,38 \%)$ & $1(11,11 \%)$ & $8(22,22 \%)$ & $35(22,2 \%)$ \\
\hline
\end{tabular}

Tabel 2. Distribusi karakteristik subjek penelitian berdasarkan tingkat obesitas $(n=158)$

\begin{tabular}{cccccccccc}
\hline \multirow{2}{*}{$\begin{array}{c}\text { Jenis } \\
\text { kelamin }\end{array}$} & \multicolumn{2}{c}{$\begin{array}{c}\text { Obesitas } \\
\text { berat }\end{array}$} & \multicolumn{2}{c}{$\begin{array}{c}\text { Obesitas } \\
\text { sedang }\end{array}$} & \multicolumn{2}{c}{$\begin{array}{c}\text { Obesitas } \\
\text { ringan }\end{array}$} & \multicolumn{2}{c}{ Total } \\
\cline { 2 - 10 } & $\mathbf{n}$ & $\%$ & $\mathbf{n}$ & $\%$ & $\mathbf{n}$ & $\%$ & $\mathbf{n}$ & $\%$ \\
\hline Laki-laki & 48 & 47,06 & 35 & 34,31 & 19 & 18,63 & 102 & 100 \\
Perempuan & 4 & 7,14 & 24 & 42,86 & 28 & 50 & 56 & 100 \\
\hline
\end{tabular}

Tabel 3. Hubungan kemampuan motorik kasar anak dengan obesitas

\begin{tabular}{lcc}
\hline $\begin{array}{c}\text { Kemampuan motorik kasar } \\
\text { anak }\end{array}$ & $\mathbf{r}$ & Sig \\
\hline Kemampuan motorik kasar & $-0,465$ & $0,000^{*}$ \\
Lempar dengan target & $-0,374$ & $0,000^{*}$ \\
Kelenturan & 0,067 & 0,403 \\
Standing long jump & $-0,036$ & 0,657 \\
Squat & $-0,249$ & $0,002^{*}$ \\
Push up & $-0,270$ & $0,001^{*}$ \\
Keseimbangan balok kecil & $-0,134$ & 0,093 \\
Keseimbangan balok besar & $-0,131$ & 0,101 \\
Lari kelincahan & 0,038 & 0,639 \\
\hline
\end{tabular}

Keterangan $={ }^{*}$ Sig $<0,05$

Kemampuan melempar, squat, dan push up menunjukkan adanya hubungan negatif antara tingkat obesitas dan kemampuan motorik karena parameter obesitas yang diambil tepat yaitu dengan mengambil tebal lipatan lemak pada daerah betis dan trisep. Sehingga terdapat perbedaan lemak pada tingkatan obesitas yang menyebabkan tampaknya perbedaan kemampuan motorik kasar anak pada ketiga kemampuan tersebut.

Kemampuan kelenturan, standing long jump, keseimbangan, dan lari kelincahan tidak menunjukkan adanya hubungan antara tingkat obesitas dan kemampuan motorik kasar anak karena parameter tingkat obesitas yang digunakan kurang tepat. Salah satu faktor yang mempengaruhi kemampuan kelenturan dengan pengukuran sit and reach adalah tebal lemak pada daerah perut. Penelitian ini tidak menggunakan pengukuran tebal lemak pada daerah perut, sehingga tidak terdapat perbedaan kemampuan meraih (kelenturan) pada berbagai tingkat obesitas. Pengukuran tebal lemak yang tepat untuk membedakan kelenturan dengan tingkat obesitas adalah dengan mengukur tebal lipatan lemak pada illiac creast skinfold dan abdominal skinfold.

Tidak ada hubungan pada kemampuan standing long jump dengan tingkat obesitas dalam penelitian ini disebabkan oleh pengukuran tebal lipatan lemak pada penelitian ini kurang tepat untuk menjaring adanya perbedaan kemampuan standing long jump pada berbagai tingkatan obesitas. Pengukuran tebal lemak untuk membedakan kemampuan standing long jump dengan tingkat obesitas yang paling tepat adalah dengan mengukur chest skinfold, thigh skinfold, dan calf skinfold. Sedangkan pengukuran pada thigh skinfold dan calf skinfold tepat digunakan sebagai parameter membedakan tingkat obesitas anak untuk mengukur kemampuan keseimbangan dan lari kelincahan.

Berdasarkan hasil penelitian dapat diketahui bahwa siswa penderita obesitas termasuk dalam kategori kemampuan motorik kasar kurang dan tidak ada siswa penderita obesitas yang termasuk dalam kategori kemampuan motorik kasar baik (Tabel 4). Kemampuan motorik kasar pada siswa penderita obesitas di kota Yogyakarta menunjukkan skor tertinggi 410 sedangkan skor terendah 92. Dari data tersebut diperoleh nilai ratarata (mean) sebesar 217,8267; median 207,83; modus 223; standar deviasi sebesar 62,2573.

Perkembangan kemampuan fisik yang tampak pada anak meliputi kekuatan, fleksibilitas, dan keseimbangan. Perkembangan kemampuan gerak adalah sejalan dengan perkembangan koordinasi, fleksibilitas, dan keseimbangan. Gerak bisa diidentifikasikan berdasarkan peningkatan efisiensi, kelancaran, kontrol, dan variasi 
Tabel 4. Distribusi subjek penelitian berdasarkan kemampuan motorik kasar anak dan tingkat obesitas

\begin{tabular}{ccccccccc}
\hline $\begin{array}{c}\text { Kategori } \\
\text { kemampuan } \\
\text { motorik } \\
\text { kasar anak }\end{array}$ & $\begin{array}{c}\text { Obesitas } \\
\text { berat }\end{array}$ & $\begin{array}{c}\text { Obesitas } \\
\text { sedang }\end{array}$ & $\begin{array}{c}\text { Obesitas } \\
\text { ringan }\end{array}$ & Total \\
\hline J & $\%$ & $\mathbf{n}$ & $\%$ & $\mathbf{n}$ & $\%$ & $\mathbf{n}$ & $\%$ \\
\hline Jelek & 39 & 54,93 & 22 & 30,99 & 10 & 14,08 & 71 & 100 \\
Kurang & 12 & 15,79 & 30 & 39,47 & 34 & 44,74 & 76 & 100 \\
Cukup & 1 & 9,09 & 7 & 63,64 & 3 & 27,27 & 11 & 100 \\
\hline
\end{tabular}

gerakan serta besarnya tenaga yang bisa disalurkan melalui gerakan (11). Anak-anak dapat melakukan tugas perkembangan pada usianya dengan baik apabila tidak ada faktor yang menghalangi tugas perkembangannya, selain itu mereka juga membutuhkan rangsangan. Anak obesitas akan mengalami kesulitan dalam melakukan aktivitas sehari-hari.

Semua anak yang dijadikan subjek dalam penelitian ini mengalami kesulitan untuk melakukan sit and reach karena faktor lemak di daerah perut yang terlalu banyak, sehingga mereka tidak mampu untuk membungkukkan badannya ke depan. Bahkan dalam pelaksanaannya, anak-anak yang dijadikan subjek penelitian ini mengalami kesulitan untuk duduk tegak tanpa kursi dengan posisi kaki ke depan. Kemampuan yang lain seperti standing long jump, keseimbangan, dan kelincahan tidak menunjukkan adanya hubungan yang signifikan antara tingkat obesitas dan kemampuan anak. Adanya kadar lemak yang tinggi pada tubuh anak-anak tersebut tidak mempengaruhi kinerja mereka dalam melakukan standing long jump, tingkat keseimbangan, dan kelincahan mereka. Kemungkinan besar karena kemampuan ini didukung oleh adanya kebiasaan sehari-hari mereka.

Hal ini sejalan dengan penelitian yang dilakukan di Jerman mengenai hubungan body mass index (BMI), kebiasaan meluangkan waktu kosong, dan kemampuan motorik. Penelitian tersebut menyatakan bahwa kelompok anak yang menderita kegemukan atau obesitas menunjukkan hasil yang lebih buruk dibandingkan dengan anak yang normal atau kurus, bahkan setelah disesuaikan dengan jenis kelamin dan usia (pada setiap kasus nilai $p<0,001$ ). Anak-anak dengan aktivitas yang aktif mencapai motor quotient (MQ) yang paling tinggi $(p=0,035)$. Obesitas dihubungkan dengan kekurangan pada perkembangan motorik kasar dan daya tahan. Gaya hidup yang aktif berhubungan positif dengan perkembangan motorik kasar pada anak (12).

Demikian juga dengan penelitian yang dilakukan di New Zealand menunjukkan bahwa BMI dan prevalensi terjadinya kegemukan dalam berbagai usia secara signifikan berhubungan dengan jumlah jam menonton televisi (13). Faktor-faktor yang mempengaruhi perkembangan motorik salah satunya adalah aktivitas (14). Adanya rangsangan, dorongan, dan kesempatan untuk menggerakkan semua bagian tubuh akan mempercepat perkembangan motorik, dan adanya perlindungan yang berlebihan akan melumpuhkan kesiapan berkembangnya kemampuan motorik (1).

Anak yang kelebihan berat badan dapat menderita masalah kesehatan yang cukup serius, seperti diabetes dan penyakit jantung, dan sering kali juga membawa kondisi ini sampai ke masa dewasanya. Faktor risiko yang ada pada masa kanak-kanak (termasuk tekanan darah tinggi, kolesterol tinggi, dan diabetes) dapat menyebabkan terjadinya masalah medis saat mereka beranjak dewasa seperti penyakit jantung, gagal jantung, dan stroke. Mencegah atau menangani obesitas pada anak-anak dapat mengurangi risiko terjadinya masalah kesehatan saat mereka dewasa. Sehingga memaksimalkan aktivitas fisik bagi anak sangat penting selain untuk merangsang perkembangan motorik kasar juga dapat berfungsi sebagai pengendali berat badan anak supaya anak tidak mengalami kegemukan dan atau obesitas.

Obesitas merupakan keadaan patologik dengan terdapatnya penimbunan lemak yang berlebihan daripada yang diperlukan untuk fungsi tubuh (15). Kebutuhan kalori anak usia 7-9 tahun sebesar $1860 \mathrm{kkal}$ dan untuk usia 10-12 tahun sebesar 1950 kkal (16). Kalori yang masuk apabila tidak dikeluarkan maka akan disimpan di dalam tubuh dalam bentuk lemak, sehingga anak bisa mengalami kegemukan atau obesitas. Supaya kalori tersebut tidak disimpan oleh tubuh dalam bentuk lemak maka harus dikeluarkan dengan melakukan berbagai aktivitas fisik seperti olahraga. Menurunkan berat badan (membuang cadangan lemak) diperlukan defisit pemasukan kalori sekitar 500 kkal/hari, sehingga anjuran asupan berkisar $1300 \mathrm{kkal}$ pada wanita dan 1600 kkal pada pria (17). Beraktivitas fisik sehari-hari (seperti menyapu, berkebun, mencuci, dan lain-lain) mampu membantu membakar kalori rata-rata sebesar 80-175 kkal. Sedangkan olahraga dengan intensitas ringan akan membantu membakar kalori yang tersimpan dalam tubuh rata-rata sebesar 150-300 kkal (18).

Pencegahan adalah strategi kunci untuk mengendalikan obesitas yang sedang mewabah sekarang. Pencegahan meliputi pencegahan utama dari kegemukan atau obesitas, pencegahan berat beban sekunder mengikuti penurunan berat beban, dan menghindari peningkatan berat beban para orang obes yang tidak mampu untuk menurunkan berat badan (19). Aktivitas olahraga yang dianjurkan untuk menanggulangi obesitas adalah olahraga yang bersifat aerobik. Ciri olahraga aerobik adalah olahraga dengan intensitas rendah dan dilakukan dalam waktu yang lama secara teratur dan terus menerus selama minimal $\mathbf{3 0}$ menit. Energi yang disediakan melalui sistem energi aerobik yaitu pemecahan zat gizi bakar (karbohidrat, lemak, dan protein) dengan bantuan oksigen (20).

Upaya untuk mengatasi obesitas adalah dengan melakukan perubahan pola hidup yaitu mengatur pola makan dan meningkatkan aktivitas fisik. Pembatasan 
kalori hanya dapat menurunkan berat badan dan kurang berdampak baik pada lemak darah. Sedangkan apabila ditambah dengan olahraga selain dapat menurunkan berat badan (karena jaringan lemak digantikan jaringan otot yang lebih berat) tetapi juga dapat memperbaiki profil lemak darah yaitu menurunkan kolesterol LDL, trigliserida, dan meningkatkan kolesterol HDL.

\section{KESIMPULAN DAN SARAN}

Sebagian besar siswa laki-laki mengalami obesitas berat sedangkan pada siswa perempuan sebagian besar mengalami obesitas ringan. Lebih dari separuh siswa yang mengalami obesitas berat memiliki kemampuan motorik kasar yang jelek sedangkan pada obesitas sedang dan obesitas ringan hampir separuhnya memiliki kemampuan motorik kasar yang kurang. Kemampuan motorik kasar berhubungan terbalik dengan kejadian obesitas. Jadi semakin tinggi tingkat obesitas anak maka kemampuan motorik kasar anak semakin rendah.

Perlu diadakan penelitian lebih dalam mengenai faktor-faktor yang mempengaruhi kemampuan motorik kasar anak. Orangtua harus mengatur keseimbangan aktivitas fisik dan asupan makanan bagi anak-anaknya sehingga anak tidak mengalami obesitas. Guru pendidikan jasmani perlu mendesain aktivitas jasmani yang sesuai untuk siswa yang mengalami obesitas sehingga mampu meningkatkan aktivitas jasmani dan kemampuan motorik kasar anak obesitas.

\section{RUJUKAN}

1. Hurlock E. Perkembangan anak. Edisi keenam. Jakarta: PT Gelora Aksara Pratama; 1987.

2. Baur LA. Child and adolescent obesity in the 21st century: an Australian perspective. Asia Pacific Journal Clinical Nutrition 2002; 11(Suppl): S524-28.

3. WHO. 10 things you need to know about obesity. Istambul: WHO European Ministerial Conference on Counteracting Obesity; 2006.

4. Mahdiah, Hadi H, Susetyowati. Prevalensi obesitas dan hubungan konsumsi fast food dengan kejadian obesitas pada remaja SLTP kota dan desa di Daerah Istimewa Yogyakarta. Jurnal Gizi Klinik Indonesia 2004; 1(2): 77-85

5. Padmiari IAE. Konsumsi fast food sebagai faktor risiko obesitas pada anak SD [Tesis]. Yogyakarta: UGM; 2001.
6. Mendoza JA, Zimmerman FJ, Christakis DA. Television viewing, computer use, obesity, and adiposity in US preschool children. International Journal of Behavioral Nutrition and Physical Activity 2007; 4(44).

7. Huriyati E, Julia M. Tekanan darah siswa sekolah dasar obes dan tidak obes di Kota Yogyakarta. Jurnal Gizi Klinik Indonesia 2009; 6(2): 60-3.

8. Basuki S, Julia M, Machfudz S. Kejadian mikropenis pada anak obes. Jurnal Gizi Klinik Indonesia 2009; 6(1): 8-12.

9. Lemeshow S, Hosmer Jr.DW, Klar J. Adequacy of sample size in health studies. Pramono D. 1997 (Alih bahasa). Yogyakarta: Gadjah Mada University Press; 1997.

10. Baumgartner T, Jackson AS. Measurement for evaluation in physical education and exercise sciene. Dubuque: Brown\&Benchmark Published; 1995.

11. Widayatun TR. IImu perilaku. Jakarta: PT. Fajar Interpratama; 1999.

12. Graf C, Koch B, Kretschmann-Kandel E, Falkowski G, Christ H, Coburger S, Lehmacher W, Bjarnason-Wehrens B, Platen P, Tokarski W, Predel HG, Dordell S. Correlation between BMI, leisure habits and motor abilities in childhood (CHILT-Project). International Journal Of Obesity 2004; 28: 22-6.

13. Hancox RJ, Poulton R. Watching television is associated with childhood obesity: but is it clinical important?. International Journal of Obesity 2006; 30: 171-5.

14. Suprandjono. Gangguan pertumbuhan pada anak balita. Makalah pada Penataran Fisiroterapi. Pengenalan awal kelainan tumbuh kembang anak balita dan tindakan penanggulangannya. Yogyakarta: FK UGM; 1986

15. Pudjiadi S. Obesitas pada anak [serial online] 2007 [cited 2007 Agustus 8]. Avaliable from: http://www.kalbefarma. com/files/cdk/files/07_ObesitasPadaAnak.pdf/07.

16. Pudjiadi S. Ilmu gizi klinis pada anak. Jakarta: Fakultas Kedokteran Universitas Indonesia; 2005.

17. Darmoutomo E. Mencegah penyakit akibat kegemukan dengan asupan nutrisi [serial online] 2007 [cited 2008 Sept 11]. Avaliable from:http://www.obesitas.web.id/ obe-news(i)24.html

18. Wirakusumah ES. Cara aman dan efektif menurunkan berat badan. Jakarta: Gramedia Pustaka Utama; 1994.

19. Dehgan, Danesh NA, Merchant AT. Review: childhood obesity, prevalence and prevention. Nutrition Journal 2005; 4(24).

20. Irianto DP. Panduan gizi lengkap keluarga dan olahragawan. Yogyakarta: Andi Offset; 1997. 